\title{
Teknologi Produksi Abon Daging Rusa Dengan Penambahan Herbal Sebagai Pangan Unggulan Pada Era Normal Baru
}

\section{The use of Herbal in the Technology of Venison Floss Production as Priority Food in New Normal Era}

\author{
Sangle Yohannes Randa ${ }^{1 *}$, Siska Tirajoh ${ }^{2)}$, Osfar Sjofjan ${ }^{3)}$ \\ ${ }^{1)}$ Fakultas Peternakan, Universitas Papua, Jl. G Salju Amban, Manokwari \\ ${ }^{2}$ Balai Pengkajian Teknologi Pertanian Papua, Jl. Yahim No. 49, Sentani, Jayapura, Papua \\ ${ }^{3)}$ Fakultas Peternakan, Universitas Brawijaya, Jl. Veteran, Malang
}

\section{Article history \\ Received: Jan 25, 2021; \\ Accepted: Dec 23, 2021 \\ * Corresponding author: \\ E-mail: \\ sangleranda@gmail.com \\ DOI: \\ 10.46549/jipvet.v11i3.174

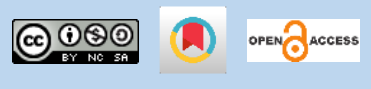

\begin{abstract}
This study aims to improve the nutritional quality of venison floss by modifying the the technology process of floss making with adding red fruit oil (Pandanus conoideus L) and kebar grass extract (Biophytum petersianum) as a source of natural antioxidants. The results showed that the nutritional value of floss was influenced by the use of these herbal. Supplementation of antioxidant is to potentially extend the shelf-life of floss as indicated in decreasing the value of water activity (Aw) and thiobarburic acid (TBA). The Aw value decreased from 0.756 to 0.701 , and TBA decreased from 0.139 to $0.055 \mathrm{mg} / \mathrm{kg}$. The protein of floss increased from 33.20 to $35.60 \%$. The result also showed that the content of antioxidant increased which is indicated by the increasing of beta-carotene content from $0.0087 \mathrm{mg} / 100$ gram to $0.81 \mathrm{mg} / 100$ gram. Results also showed that the use of red fruit oil extract and kebar grass extract decreased the content of saturated fatty acids, meanwhile in unsaturated fatty acids it increased arachidonic fatty acids.
\end{abstract}

Keywords: Antioxidant; Beta-caroten; Kebar grass; Red-fruit oil; Venison floss.

\section{Abstrak}

Penelitian ini bertujuan meningkatkan kualitas nutrisi abon daging rusa dengan memodifikasi proses teknologi produksinya dengan penambahan ekstrak minyak buah merah (Pandanus conoideus L) dan ekstrak rumput kebar (Biophytum petersianum) sebagai sumber antioksidan alami. Hasil penelitian memperlihatkan bahwa nilai nutrisi produk olahan daging dipengaruhi oleh adanya penambahan senyawa antioksidan. Pemberian suplementasi bahan sumber antioksidan meningkatkan daya awet pada abon yang ditunjukkan dengan penurunan nilai aktivitas air $(A w)$ dan nilai thiobarburic acid (TBA). Nilai $A w$ abon menurun dari 0,756 menjadi 0,701, dan nilai TBA-nya menurun dari 0,139 menjadi $0,055 \mathrm{mg} / \mathrm{kg}$. Nilai nutrisi terjadi pada nilai protein yang meningkat dari 33,20 menjadi $35,60 \%$. Sebagai sumber antioksidan terlihat pada peningkatan kandungan beta-karoten dari $0,0087 \mathrm{mg} / 100$ gram menjadi $0,81 \mathrm{mg} / 100$ gram. Faktor penting lainnya dengan penggunaan ekstrak minyak buah merah dan ekstrak rumput kebar yakni adanya penurunan yang signifikan pada kandungan asam-asam lemak jenuh, akan tetapi pada asam-asam lemak tidak jenuh terjadi peningkatan pada asam lemak arakidonat.

Kata kunci: Abon rusa; Beta-karoten; Herbal antioksidant; Minyak buah-merah; Rumput kebar. 


\section{PENDAHULUAN}

Ketahanan hidup manusia pada era normal baru (new normal life) pasca pandemi virus corona (Covid-19) ikut dipengaruhi oleh asupan pangan bergizi, yang berfungsi meningkatkan imunitas tubuh. Daging merupakan pangan penting sebagai penyedia berbagai jenis nutrisi, asam-asam amino, asamasam lemak, vitamin dan mineral, (Pereira \& Vicente, 2013; Wyness, 2016) yang diperlukan tubuh manusia bagi pembentukan antibodi dalam mempertahankan tubuh terhadap infeksi yang diakibatkan oleh berbagai mikroorganisme pathogen, seperti bakteri dan virus (Gombart et al., 2020).

Potensi penyedia daging hewani salah satunya berasal dari daging rusa. Sebagai penghasil daging, hewan rusa sudah lama dimanfaatkan oleh masyarakat sebagai pangan sumber hewani (Semiadi et al., 2008; Randa et al., 2014). Rusa dewasa dapat menghasilkan karkas berkisar 54-70\% dari bobot hidup ((Samsudewa \& Capitan, 2011; Maryanto \& Saim, 2013). Pemanfaatan rusa di Indonesia umumnya masih mengandalkan potensi alamiah dan hanya terbatas dalam pemenuhan kebutuhan keluarga. Diperkirakan populasi rusa yang ada pada saat ini tidak kurang dari 10.000 ekor yang dikelompokkan ke dalam lima spesies yang tersebar hampir di seluruh pulau-pulau di Indonesia. Populasi terbesar adalah yang berasal dari spesies rusa timor (Cervus timorensis) (Puhun et al., 2017).

Kualitas daging rusa sangat disukai karena teksturnya yang lembut dan berserat halus. Kandungan protein dan zat besi cukup tinggi, sedangkan kandungan lemak dan kolesterolnya relatif lebih rendah dibandingkan dengan beberapa daging konvensional yang ada (Brahmantiyo et al., 2013). Kandungan protein daging rusa $23,36 \%$ lebih tinggi dibandingkan dengan yang terdapat pada daging babi $21,32 \%$ atau pada daging sapi $19,61 \%$. Kandungan lemak pada daging rusa $1,90 \%$ lebih rendah daripada yang terkandung pada daging babi 2,77\%. Demikian pula kandungan kholesterol pada daging rusa $70,57 \%$ lebih rendah dibandingkan dengan yang terdapat pada daging sapi $76,31 \%$. Dilaporkan juga bahwa kandungan omega-3 dan omega- 6 pada daging rusa lebih tinggi dibandingkan dengan yang terkandung pada daging babi dan daging sapi (Strazdina et al., 2013).

Teknologi pembuatan abon daging yang sudah umum dilakukan oleh masyarakat yaitu dengan beberapa penambahan bumbu-bumbu dapur yang berfungsi sebagai penyedap rasa dan juga sebagai pengawet alamiah. Di Papua terdapat sejumlah herbal yang dapat dimanfaatkan sebagai bahan pengawet alami yang bermanfaat bagi kesehatan. Herbal asal Papua yang beberapa tahun terakhir diminati oleh konsumen adalah sari (minyak) buah merah (Pandanus conoideus L) dan rumput kebar (Biophytum petersianum). Hasil kajian pada kedua bahan herbal ini dilaporkan mengandung beberapa senyawa antioksidan alami seperti beta-caroten dan alfa-tokoferol, juga terdapat beberapa komponen organik aktif yang diperlukan sebagai sumber pemicu peningkatan imunitas tubuh manusia (Roreng, 2014; Santoso et al., 2018). Pada penelitian ini proses pengolahan abon dimodifikasi dengan penambahan ekstrak herbal asal Papua yang diperuntukkan sebagai sumber antioksidan alami dalam memperkaya kualitas abon yang diproduksi, yang diharapkan dapat meningkatkan imunitas tubuh manusia yang sangat diperlukan dalam menghadapi serangan wabah virus corona.

\section{MATERI DAN METODE}

Bahan yang dipergunakan dalam penelitian ini terdiri atas bahan utama dan bahan pelengkap. Bahan utama yaitu sari (minyak) buah merah (Pandanus conoideus L), rumput kebar (Biophytum petersianum), dan daging rusa bagian paha belakang. Bahan pelengkap terdiri dari bumbu-bumbu yang ditambahkan dalam memberi cita rasa pada abon yang diproduksi.

Penelitian dilakukan dalam dua tahapan, yakni tahapan produksi dan tahapan analisis produk. Pada tahapan produksi pembuatan abon yaitu dengan menggunakan daging rusa segar yang dibersihkan dari jaringan ikat dan lemak. Daging dipotong-potong kecil berbentuk kubus dengan ukuran sekitar $4 \times 4 \times 4$ $\mathrm{cm}$ dan dicuci bersih. Potongan daging direbus dengan air sebanyak 2 liter/kg bahan daging dan ditambahkan ke dalamnya rumput kebar sebanyak $50 \mathrm{~g}$ segar (kering angin)/kg daging segar. Lama perebusan satu jam. Rebusan 
daging ditumbuk halus dan dipisahkan seratnya. Semua bumbu dicampur dan diblender halus, selanjutnya ditumis dengan sedikit minyak. Suwiran daging dimasak dengan santan dan ditambahkan dengan bumbu dan setelah itu ditambahkan $5 \mathrm{cc}$ minyak buah merah. Setelah santan kering, daging yang telah dimasak digoreng kembali, kemudian ditiriskan. Abon yang dihasilkan dianalisis kualitasnya dengan menggunakan dua variabel utama, yaitu kandungan nutrisi dan aktivitas antioksidan.

\section{HASIL DAN PEMBAHASAN}

\section{KADAR AIR}

Hasil penelitian memperlihatkan bahwa pengaruh penggunaan minyak buah merah dan ekstrak rumput kebar meskipun tidak secara signifikan mempengaruhi kadar air pada produk abon, akan tetapi terdapat kecenderungan terjadinya penurunan kadar air.
Kadar air pada abon yang diproduksi pada penelitian ini $19,27 \%$ lebih rendah dari abon tanpa perlakuan herbal 19,33\% (Randa et al., 2014). Nilai kadar air pada abon daging rusa yang diproduksi ini masih lebih tinggi dari yang terdapat pada salah satu produk abon daging ayam 12,35 \% (Halid dan Rakim, 2018) atau , masih dalam kisaran kandungan air pada beberapa abon daging yang lain seperti abon sapi $17,69 \%$, abon kambing, 19,29\%, dan abon daging babi 19,59\% (Omojola et al., 2014). Meskipun kadar air pada produk masih lebih tinggi dibandingkan dengan kadar air yang dianjurkan oleh SNI (BSN, 1995), yakni maksimum $7 \%$, akan tetapi aktivitas air pada produk abon ini yang sebesar 0,70 menunjukkan bahwa kondisi ini masih relatif baik dalam penghambatan pertumbuhan mikroorganisme jamur (Leistner \& Rödel, 1975; Randa et al., 2014; Aminzare et al., 2016).

Tabel 1. Kandungan nutrisi pada abon daging rusa

\begin{tabular}{lcc}
\hline \multirow{2}{*}{ Variabel Nutrisi } & \multicolumn{2}{c}{ Perlakuan Proses Pembuatan Abon } \\
\cline { 2 - 3 } & Tanpa Herbal (Kontrol) & Dengan Herbal \\
\hline Air (\%) & 19,33 & 19,27 \\
Aktivitas Air (Aw) & 0,76 & 0,70 \\
Protein kasar (\%) & 33,2 & 35,6 \\
Beta Karoten (ppm) & 0,087 & 8,100 \\
\hline
\end{tabular}

\section{PROTEIN}

Penggunaan herbal antioksidan dalam proses produksi abon rusa meningkatkan kandungan protein sebesar 7,2\%. Peningkatan protein pada abon lebih tinggi lagi bilamana dibandingkan dari daging segar, yakni terjadi peningkatan sebesar $53,2 \%$ atau dua kali peningkatannya. Hal ini juga dilaporkan oleh Omojola et al., (2014), kandungan protein abon yang diproduksi dari daging sapi, kambing, dan babi berturut-turut sebesar 39,75\%, 46,73\% dan $41,78 \%$, atau telah terjadi peningkatan hampir dua kali lipat dibandingkan dengan kandungan protein pada keadaan segar. Hal memperlihatkan bahwa pengolahan daging segar menjadi abon akan memberikan penyediaan protein yang sangat penting bagi kebutuhan nutrisi manusia.

\section{BETA KAROTEN}

Senyawa beta-karoten merupakan salah satu komponen nutrisi yang banyak terdapat pada ekstrak buah merah dan rumput kebar. Kandungan beta-karoten yang tinggi pada kedua herbal tersebut menyebabkan buah merah dan rumput kebar kini popular dikonsumsi oleh masyarakat sebagai pangan suplemen sumber antioksidan. Roreng et al., (2016) melaporkan bahwa kandungan total karoten pada buah merah lebih dari $200 \mathrm{mg} / 100$ g. Penelitian Sarungallo et al., (2015) melaporkan bahwa kandungan beta-karoten pada buah merah dapat mencapai $11,8 \mathrm{mg} / 100$ $\mathrm{g}$ dengan total karoten berkisar 302,7-1996 $\mathrm{mg} / 100 \mathrm{~g}$.

Seperti halnya dengan buah merah, rumput kebar yang merupakan tumbuhan herba dari kelas Oxalidaceae, sudah sejak lama dimanfaatkan sebagai tanaman obat oleh 
masyarakat di Papua. Dinamakan rumput kebar karena selama ini tanaman tersebut ditemukan di wilayah Kebar, yaitu sebuah kecamatan dari kabupaten Manokwari, Papua Barat. Masyarakat mengenal tanaman tersebut sebagai obat tradisional yang diolah secara sederhana untuk berbagai keperluan kesehatan. (Sembiring \& Darwati, 2016) menyebutkan bahwa tumbuhan ini dapat dimanfaatkan sebagai obat kumur untuk sariawan, penawar racun gigitan ular dan obat pencuci perut untuk anak. Salah satu khasiat utama yang dipercaya oleh masyarakat dari tanaman ini adalah sebagai obat kesuburan.

Berdasarkan pada pengetahuan tradisional masyarakat terhadap manfaat rumput kebar, kini tanaman ini mulai banyak diminati oleh sejumlah peneliti yang mempelajari kandungan nutrisi dan komponen organik lainnya yang terdapat pada tanaman tersebut. (Darwati, 2014) melaporkan bahwa analisis komposisi kimia yang terkandung dalam rumput kebar selain adanya nutrisi umum seperti serat kasar, lemak, protein, karbohidrat, tanaman ini juga mengandung beberapa senyawa kimia yang tergolong sebagai sumber antioksidan, misalnya vitamin-A yang ditemukan sebanyak $8057,19 \mathrm{IU} / 100$ gram atau sekitar $4,8 \mathrm{mg} / 100$ gram beta-karoten. Penelitian (Widodo et al., 2020) menyebutkan kandungan vitamin-A pada rumput kebar 199,30 IU/100 gram atau setara dengan $0,12 \mathrm{mg} / 100$ gram beta-karoten.

Penggunaan minyak buah merah dan ekstrak rumput kebar dalam proses pembuatan abon daging rusa dapat meningkatkan kandungan beta-karoten dari $0,0087 \mathrm{mg} / 100$ gram menjadi $0,81 \mathrm{mg} / 100$ gram (Randa et al., 2014). Berdasarkan ketetapan AKG yang diatur dalam Permenkes RI nomor 28 tahun 2019, rata-rata kebutuhan vitamin A bagi setiap orang per hari berkisar 400-600 RE atau setara dengan 1,2-2,4 mg beta-karoten per hari, maka ketersediaan beta-karoten pada abon yang diberi penambahan minyak buah merah dan ekstrak rumput kebar sangat direkomendasikan untuk dimanfaatkan sebagai pangan dalam memenuhi kebutuhan vitamin-A bagi manusia. Kecukupan asupan vitamin A bagi manusia sangat berperan penting dalam membangun imunitas tubuh untuk menangkal serangan mikroorganisme pathogen yang masuk ke dalam tubuh seseorang.

\section{ASAM-ASAM LEMAK}

Penggunaan minyak buah merah dan ekstrak rumput kebar dalam pembuatan abon daging rusa sebagai sumber beta-karoten berpotensi menurunkan kandungan asam-asam lemak, terutama asam lemak jenuh. Tabel 2 memperlihatkan bahwa total Asam-asam Lemak Jenuh menurun 40,11\%, sedangkan yang tidak jenuh 27,0\% (Randa et al., 2014). Hasil ini sangat baik sebab dengan rendahnya asam lemak jenuh pada abon yang diproduksi ini tentu meningkatkan nilai higienisnya. Makanan dengan lemak jenuh tinggi dapat mempengaruhi kesehatan manusia seperti peningkatan kolesterol darah, juga sebagai pemicu munculnya penyakit degeneratif (Tuminah, 2009). Penurunan tingkat kandungan asam-asam lemak jenuh dengan pemberian bahan sumber $\beta$-karoten, juga dilaporkan oleh Wardiny et al., (2020) yang melaporkan bahwa penggunaan daun tanaman noni (Morinda citrifolia) yang kaya $\beta$-karoten menurunkan kadar kolesterol dan asam-asam lemak jenuh.

Penurunan asam-asam lemak tidak jenuh pada abon yang mendapat perlakuan, tidak diikuti oleh asam arakidonat yang sebaliknya mengalami peningkatan. Hal ini masih sejalan juga dengan penelitian Wardiny et al., (2020) yang memperlihatkan adanya peningkatan pada beberapa senyawa asam-asam lemak tidak jenuh pada ayam kampung yang diberi pakan sumber $\beta$-karoten. Sebagai salah satu kelompok dari Omega-6, asam arakidonat sangat berfungsi dalam meningkatkan kekebalan tubuh, terutama dalam menangkal adanya paparan virus atau mikroorganisme lainnya (Idrus, 2015). 
Tabel 2. Kandungan asam-asam lemak abon rusa

\begin{tabular}{lll}
\hline \multirow{2}{*}{ Komponen Asam Lemak } & \multicolumn{2}{c}{ Perlakuan Proses Pembuatan Abon } \\
\cline { 2 - 3 } Asam Lemak Jenuh (ALJ) & Tanpa Herbal (Kontrol) & \multicolumn{1}{c}{ Dengan Herbal } \\
Laurat (C12:0) & $408,79 \pm 7,52$ & $190,18 \pm 1,06$ \\
Miristat (C14:0) & $233,46 \pm 4,33$ & $105,50 \pm 0,41$ \\
Palmitat (C16:0) & $2.742,13 \pm 51,67$ & $1.669,81 \pm 6,60$ \\
Stearat (C18:0) & $625,18 \pm 16,06$ & $439,51 \pm 1,69$ \\
Arakidat (C20:0) & $44,33 \pm 0,97$ & $22,40 \pm 0,06$ \\
Subtotal & $4.053,88 \pm 80,56$ & $2.427,40 \pm 9.83$ \\
Asam Lemak Tidak Jenuh (ALTJ) & & \\
Palmitoleat (C16:1) & $47,97 \pm 0,94$ & $30,71 \pm 26,02$ \\
Oleat (C18:1) & $2.537,52 \pm 55,05$ \\
Linoleat (C18:2) & $1.511,69 \pm 28,62$ & $2.266,23 \pm 8,98$ \\
Linolenat (C18:3) & $426,95 \pm 8,06$ & $537,63 \pm 0,23$ \\
Arakidonat (C20:4) & $11,80 \pm 0,04$ & $47,98 \pm 0,54$ \\
\hline Subtotal & $4.535,93 \pm 92,72$ & $12,68 \pm 0,10$ \\
\hline
\end{tabular}

\section{AKTIVITAS ANTIOKSIDAN}

Gambar 1. menunjukkan bahwa penggunaan herbal dalam proses pembuatan abon daging rusa memberikan respon positif. Penurunan nilai TBA (Thiobarbituric Acid) sebesar 60,4\% mengindikasikan bahwa antioksidan pada abon mampu memperlambat adanya proses ketengikan. Dengan demikian bahwa abon yang diberi perlakuan antioksidan alami memiliki potensi daya simpan yang lebih lama.

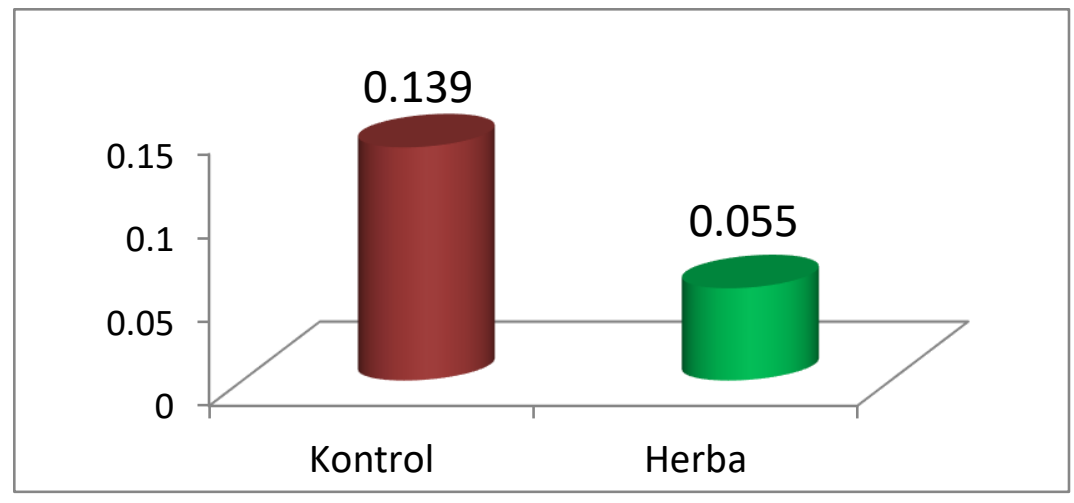

Gambar 1. Nilai TBA (mg/kg) pada abon daging rusa

\section{KESIMPULAN}

Penggunaan minyak buah merah dan ekstrak rumput kebar dalam proses pembuatan abon daging rusa dapat memperbaiki kualitas abon dan berpotensi meningkatkan masa simpan produk. Hasil penting yang diperoleh bahwa penggunaan herbal tersebut meningkatkan kandungan $\beta$-karoten pada abon yang merupakan salah satu subtansi nutrisi yang diperlukan bagi peningkatan imunitas tubuh manusia terhadap infeksi mikroorganisme pathogen.

\section{UCAPAN TERIMA KASIH}

Terima kasih disampaikan kepada Badan Penelitian dan Pengembangan Pertanian, Jakarta atas dukungan pendanaan penelitian ini.

\section{DAFTAR PUSTAKA}

Aminzare, M., Hashemi, M., Hassanzad Azar, H., \& Hejazi, J. (2016). The Use of Herbal Extracts and Essential Oils as a Potential Antimicrobial in Meat and Meat Products; A Review. Journal of Human, 
Environment, and Health Promotion. https:// doi.org/ 10.29252/jhehp.1.2.63

Brahmantiyo, B., Wirdateti, \& Semiadi, G. (2013). Karakteristik Karkas , Sifat Fisik dan Kimia Daging Rusa Sambar (Rusa unicolor ). Buletin Plasma Nutfah.

Darwati, Sembiring, B. dan Ireng. (2014). Identifikasi Komponen Kimia Aksesi Rumput Kebar (Biophytum petersianum Klotzsch) Asal Papua dan Jawa. Identification of chemical component of kebar grass accession (Biophytum petersianum Klotzsch) from Papua and Java. Buletin Tan. Rempah Dan Obat.

Gombart, A. F., Pierre, A., \& Maggini, S. (2020). A review of micronutrients and the immune system-working in harmony to reduce the risk of infection. Nutrients. https://doi.org/ 10.3390/nu12010236

Halid A,s Rakim, A. (2018). Sifat Fisik, Kimia dan Aktivitas Antioksidan Abon Daging Ayam di Kota Palu. J. Agroland 25.

Idrus, S. (2015). Asam Lemak Omega 3 dan 6 Sebagai Potensial Inhibitor Reaksi Fusi Virus Dengue. Majalah BIAM.

Leistner, L., \& Rödel, W. (1975). The Significance of Water Activity for Microorganisms in Meats. In Water Relations of Foods. https://doi.org/10.1016/b978-0-12223150-6.50022-5

Maryanto, I., \& Saim, A. (2013). Komposisi Bagian Karkas Rusa (Cervus timorensis moluccensis) dari Kawasan Das Bian, Merauke, Irian Jaya. Buletin Peternakan. https://doi.org/10.21059/buletinpeternak. v14i2.1762

Roreng, M. K. R. (2014). Carotenoids From Red Fruit (Pandanus conoideus Lam.) Extract Are Bioavailable: A Study In Rats. IOSR Journal of Pharmacy (IOSRPHR). https://doi.org/10.9790/3013-04020301116

Omojola, A., Kassim, O., Olusola, O., Adeniji, P., \& Aremo, J. (2014). Development and Quality Evaluation of Danbunama (Meat Floss) - a Nigerian Shredded Meat Product. British Journal of Applied Science \& Technology. https://doi.org/10.9734/bjast/ 2014/10055

Pereira, P. M. de C. C., \& Vicente, A. F. dos R. B. (2013). Meat nutritional composition and nutritive role in the human diet. In Meat Science. https:// doi.org/ 10.1016/ j.meatsci.2012.09.018

Puhun, S., Kehutanan Institut Pertanian Malang Sri Sulastri, F., Kehutanan Institut Pertanian Malang Diena Widyastuti, F., \& Teknologi Pertanian Institut Pertanian Malang Abstrak, F. (2017). Pengelolaan Kesejahteraan Satwa (Animal Walfare) Rusa Timor (Rusa timorensis) di Oilsonbai Kupang. Konservasi Sumberdaya Hutan Jurnal Ilmu Ilmu Kehutanan.

Randa, S. Y., Tirajoh, S., \& Sjofjan, O. (2014). Kualitas Nutrisi Dendeng dan Abon Rusa dengan Penambahan Antioksidan Minyak Buah Merah (Pandanus conoideus L) dan Ekstrak Rumput Kebar (Biophytum petersianum). Prosiding Seminar Nasional Teknologi Peternakan dan Veteriner 2014. ICARD http://peternakan. litbang.pertanian. go.id /fullteks/semnas/pro14-109.pdf.

Roreng, M. K., Sarungallo, Z. L., Murtiningrum, M., Santoso, B., \& Latumahina, R. M. (2016). Mutu Mikrobiologis Drupa Buah Merah (Pandanus conoideus Lamk.) pada Berbagai Jenis Kemasan Selama Penyimpanan. Agrointek. https://doi.org/10.21107/agrointek.v10i2. 2471

Samsudewa, D., \& Capitan, S. S. (2011). Reproductive Behaviour Of Timor Deer (Rusa Timorensis). Wartazoa.

Santoso, B., Sarungallo, Z. L., Situngkir, R. (2018). Mutu Kimia Minyak dan Komponen Aktif Minyak Buah Merah (Pandanus conoideus L.) yang Dinetralisasi Menggunakan Larutan Alkali.

Sarungallo, Z. L., Hariyadi, P., Andarwulan, N., Purnomo, E. H., \& Wada, M. (2015). Analysis of $\alpha$-Cryptoxanthin, $\beta$ Cryptoxanthin, $\alpha$-Carotene, and $\beta$ Carotene of Pandanus Conoideus Oil by High-performance Liquid Chromatography (HPLC). Procedia Food Science. https://doi.org/10.1016/j.profoo.2015.01.0 26

Sembiring, B., \& Darwati, I. (2016). 
Identifikasi Komponen Kimia Aksesi Rumput Kebar (Biophytum petersianum) Asal Papua dan Jawa. Buletin Penelitian Tanaman Rempah Dan Obat. https://doi.org/10.21082/bullittro.v25n1.2 014.37-44

Semiadi, G., Wirdateti, Jamal, Y., \& Brahmantiyo, B. (2008). Pemanfaatan Rusa sebagai Hewan Ternak ( The Prospect of Deer as Domesticated Animal ). Seminar Nasional Teknologi Peternakan Dan Veteriner 2008.

Strazdina, V., Jemealjanovs, A., \& Šterna, V. (2013). Nutrition value of wild animal meat. Proceedings of the Latvian Academy of Sciences, Section B: Natural, Exact, and Applied Sciences. https://doi.org/10.2478/prolas-2013-0074

Tuminah, S. (2009). Efek Asam Lemak Jenuh dan Asam Lemak Tak Jenuh "Trans" Terhadap Kesehatan. Media Penelit. Dan Pengembang. Kesehat. https://doi.org/10.1007/s13398-014-0173-
7.2

Wardiny, T. M., Sumiati, S., Retnani, Y., \& Setiyono, A. (2020). Production of Functional Kampong Chicken Meat with Low Cholesterol, High Antioxidant, and Unsaturated Fatty Acids Fed Noni (Morinda citrifolia) Leaf Shoot Meal. Tropical Animal Science Journal. https://doi.org/10.5398/tasj.2020.43.1.35

Widodo, E. Y., I'tishom, R., \& Purwanto, B. (2020). Potensi Ekstrak Rumput Kebar (Biophytum petersianum Klotzsch) Dalam Mempertahankan Jumlah Sel Sertoli Mencit (Mus musculus) Model Diabetes Melitus. Jurnal Penelitian Kesehatan "SUARA FORIKES" (Journal of Health Research "Forikes Voice"). https://doi.org/ 10.33846/sf11311

Wyness, L. (2016). The role of red meat in the diet: Nutrition and health benefits. Proceedings of the Nutrition Society. https://doi.org/10.1017/S0029665115004 267 